\title{
12 ENHANCING HUMAN FLOURISHING: REFLECTIONS ON THE ZIMBABWE CATHOLIC BISHOPS' CONFERENCE AS AN ENDURING PROPHETIC VOICE (1957-2017)
}

\section{Edmore Dube ${ }^{1}$}

\section{INTRODUCTION}

Although English Jesuits attached one of their priests as chaplain to the Pioneer Column, ${ }^{2}$ which colonised Zimbabwe and named it Rhodesia under the banner of Christianity and civilisation, it became clear around 1957 that the secular state was devoid of any Christian values for human flourishing. Without any serious introspection, the Roman Catholic Church ran a risk of diluting the gospel through complicity. With the expansion of the Rhodesia (now Zimbabwe) Catholic Bishops' Conference (RCBC/ZCBC) in the 1940s and 1950s, the Church metamorphosed into a more sensitive organisation, focused on the downtrodden indigenous population with whom the "future Church" lay. The bishops stood firm in defence of Christian civilisation by resisting the racist Constitution of Rhodesia, 1969, intended to destroy racial integration by propagating separate racial development, which meant the destruction of multiracial schools, parishes, as well as clerical communities.

The RCBC reacted by forming the Catholic Commission for Justice and Peace (CCJP) in 1972, in order "to relieve the oppressed and to strive for justice for all men", which is an intrinsic aspect for human flourishing. The Church remained vocal against anything not resonating well with the common good, for such a thing was bound to impinge negatively on human progress. In the true pre-exilic prophetic style of Amos, the biblical prophet from Tekoa, the Church put itself as the vanguard against successive political regimes bent on limiting people's freedoms of choice, association, expression, participation and even access to information. The Church saw these freedoms as basic ingredients for human progress, and therefore ceaselessly fought against "state theology" at great peril for its leading members who were secretly murdered, publicly incarcerated, exiled or forced out of administrative posts. The Church was prepared to pay such a price because the bishops were convinced that piety alone was inadequate in fighting "state theology", to achieve justice which they saw as the soul of the Christian mission.

1 Edmore Dube, Senior Lecturer, Department of Philosophy and Religious Studies, Great Zimbabwe University.

2 Pioneer Column is the formal rendering for the group of fortune seekers assembled by Cecil John Rhodes for the purposes of colonising Zimbabwe in 1890. 
In exploring the Church's prophetic involvement, the chapter opens with an historical background which foregrounds the Church's reaction from 1957 onwards. The voice of the Church is unlocked through the exposition of pastoral letters, CCJP publications, church newspapers, cooperation with other churches and political mediatory expertise aimed at upholding human dignity, equality and the common good. The various publications are replete with the activities of the Church aimed at reversing racial or partisan state policies meant to limit people's progress so as to make them easy to control. Both the colonial and the post-independence governments were keen on retarding the progress of the majority, as a way of hanging on to unbridled political power. To the contrary the Church struggled to unlock human potential, irrespective of race or tribe, as the first step towards human flourishing. Thus, the Church saw each single moment of time as a kairos moment in which human flourishing could be enhanced, while the state took every opportunity to negate free community advancement for selfish ends. This clash of focus was the source of bitter rivalry between the Church and the state from 1957 to 2017.

\section{HISTORICAL BACKGROUND: FROM COOPERATION TO DISSENSION}

To understand the historical antecedents leading to the combative prophetic theology of the 1950s, it is useful to consider Swiss theologian, Jan Milic Lochman's definition of prophecy as "a question of recognising the signs of times, of not letting our 'today' slip thoughtlessly and aimlessly through our fingers but letting it be renewed and shaped". ${ }^{3}$ The Church maintains that if we want to reach our optimum levels of human flourishing, we need to have our "today" renewed and re-shaped by the Gospel of Christ. Examination of the historical background reveals that the initial Church-state rapport born out of mutual support in the days of the occupation of Zimbabwe gradually dissipated from the mid-1950s. It contends that the Church-state marriage of convenience was broken, due to serious disagreements over definitions of Christian civilisation as a source of universal human progress.

Initially, Jesuit missionaries strove to inculcate Christian civilisation as a frame of human development, but they increasingly became uncertain of their security in the Ndebele kingdom under the king, Lobengula. This forced the Catholic missionaries to abort the Matabeleland ${ }^{4}$ mission and retreat to South Africa where their security was guaranteed by the growing colonial state. ${ }^{5}$ It was at that moment that Cecil John Rhodes, a British colonial magnate, presented his plan to annex Zimbabwe through the Pioneer Column. Members of the Pioneer Column were in need of moral justification, which they believed church involvement could provide. The missionaries, for their

3 Lochman JM. 1980. Reconciliation and Liberation: Challenging a One-dimensional View of Salvation. Philadelphia: Fortress, 61.

5 Weller J and Linden J (eds). 1984. Mainstream Christianity to 1980 in Malawi, Zambia and Zimbabwe. Gweru: Mambo Press, 26. 
part, were more than willing to join the chaplaincy and medical care of the invading European force. ${ }^{6}$ They hoped that Company ${ }^{7}$ rule would provide them with ample space for unhindered evangelisation of the territory north of the Limpopo River, now Zimbabwe. That was why they complimented Star Jameson, the BSAC administrator, for pacifying the Ndebele kingdom. ${ }^{8}$ They dreamt that Ndebele pacification would enhance human flourishing through assimilation of Christian civilisation, modeled on ten Social Teachings of the Church (STC): respect for human dignity, human life, freedom of association, participation, preferential protection for the poor and vulnerable, solidarity, stewardship, subsdiarity, universal destination of the earth's goods and the common good. ${ }^{9}$

On the face of it, things moved as anticipated. Missionary security improved after the BSAC takeover of Mashonaland in 1890. Missionaries were awarded large tracts of land for mission stations; comprising churches, hospitals, formal schools and technical skills centres. Such mission packages catered for spiritual, physiological, cognitive and psychomotor development (total human formation). The Church considered total human formation as the basis for human flourishing.

The symbiotic relationship between the colonial state and the Church, however, did not endure forever. Instead it grew in inverse proportion with the increase in white population through procreation and immigration. The increase in white population meant alienation of more and more land from the black population, which the Church defined as indigenous underdevelopment. Legalisation of land appropriation, which started right from 1898, peaked with the Land Apportionment Act of 1930, which created Shona-Ndebele reserves in impoverished areas. This was further worsened by the Land Husbandry Act of 1951, which restricted the number of cattle per indigenous farmer. Cattle are, of course, central to the indigenous economy; yet 1,126,366 cattle were forcedly deposed of prior to 1979, with instances where police confiscated cattle of those who resisted curling without compensation. ${ }^{10}$ This escalated inter-racial conflict which drew the Church's attention and involvement. ${ }^{11}$ It coincided with the expanding episcopate, which could not stand by and watch things deteriorate, as archbishop Aston Chichester, SJ, the English Jesuit, had largely done. Instead the new Rhodesia Catholic Bishops'

6 Weller and Linden, Mainstream Christianity to 1980 in Malawi, Zambia and Zimbabwe, 53.

7 The British South Africa Company (BSAC) was the administrative arm of the Pioneer Column.

8 Zvobgo CJM. 1996. A History of Christian Missions in Zimbabwe 1890-1939. Gweru: Mambo Press.

9 Makamure KF. 2015. "Leadership and Catholic Social Teachings: A Talk Given to the Masvingo Diocesan Pastoral Council Members on Leadership", Gokomere Mission, 20-22 February.

10 Chitiyo TK. 2001. "Land violence and compensation”, Track Two 9(1).

11 Mupfuvi BM. 2014. Land to the People: Peasants and Nationalism in the Development of Land Ownership Structure in Zimbabwe from Pre-colonialism to the Unilateral Declaration of Independence (UDI) Period, PhD Diss, University of Salford, 9. 
Conference (RCBC) entered the fray and challenged the colonial concept of separate racial development, which the bishops saw as hindering African development.

The 1931 appointment of Aston Chichester, SJ, as the first Catholic bishop of Rhodesia had heralded the Church's constructive criticism of the colonial state. The Church hoped that the original symbiotic relationship between the Church and the state would continue to endure, for the enhancement of human development. The intransigence of the state, however, continued to embolden, due to its calculated advancement of white superiority, which culminated in mass removals of blacks from fertile lands. That widened racial gap between the rich settlers and the poor indigenes, to the great chagrin of the Church, which contested it as retrogressive. The visible cordiality between the Church and the state was buried with the retirement of the soft-spoken Chichester, the archbishop of Salisbury, in 1957. The federal state of Rhodesia and Nyasaland, the state of Southern Rhodesia and the Salisbury town council held farewell receptions for him, marking the end of an era.

The departure of Archbishop Chichester heralded the onset of combative prophetic theology. The visible dawn of the new era, with a new approach to discriminative state theology, included the proclamation in 1955 of the Diocese of Gwelo run by the Swiss Bethlehem Missionary Society $(\mathrm{SMB})^{12}$ with Aloysius Haene as bishop. The SMB were sensitive theologians, heavily influenced by the liberation theology of their missions in Latin America. It was a theology that put justice as an antecedent of peace and human development, hence the epithet: If you want peace work for justice. The new combative approach was enhanced by the opening of the Irish Carmelites run prefecture of Umtali in 1953 under the outspoken Monsignor Donal Lamont O'Carm as prefect apostolate and eventually bishop. The English and the Irish had an acrimonious history regarding British imperialism in Northern Ireland, whose justification the Irish adamantly opposed. ${ }^{13}$ The Haene-Lamont partnership saw to it that it was no longer business as usual unless the state reversed its racial "apartheid". In fact, the RCBC adjudged the colonial administration to be advancing secular notions at loggerheads with Christian values, although the State claimed to be striking "blows in defence of Christianity and the Christian civilisation". ${ }^{14}$ These contradictions inform the Church-state positions on human development from 1957 onwards.

\section{AND BEYOND: CHURCH ORGANS AS PROPHETIC VOICES}

By 1957, the situation had deteriorated, with the result that the indigenes were grieving in the semi-arid, overcrowded, and overgrazed gully-ridden reserves. ${ }^{15}$

12 Official rendering of the acronym (French).

13 Hastings A. 1989. African Catholicism. London: SCM, 23.

14 RCBC. 1976. The Road to Peace: Pastoral Guidelines. Gweru: Mambo Press, 21.

15 Dube E. 2017. "Zimbabwe Land Tenure Impact on Development and Justice Delivery", in Mawere M and Mubaya TR (eds). African Studies in the Academy: The Cornucopia of Theory, 
Villages had been restructured into linear settlements to ease collection of exorbitant taxes, which forced many indigenes into cheap labour on European lands and enterprises. The Catholic Church realised that the time for action had come, if it was to contribute to the salvation of the future church in Zimbabwe. In that regard, the RCBC distinguished itself way above many Christian communions. Canaan Sodindo Banana, a Methodist cleric and first president of independent Zimbabwe, acknowledged that "the Roman Catholic's conscious attempt to engender a lasting spirit of racial tolerance was more than any other church of that time had the will or capacity to do" ${ }^{16}$ By outpacing all other churches in assisting liberation movements and outspokenness, the Catholic Church also suffered the heaviest casualties. ${ }^{17}$ It lost twenty-three expatriate missionaries, one white bishop and a black diocesan priest, while nineteen expatriate missionaries, including Bishop Lamont, were exiled by the minority government.

Kenneth Skelton, the Anglican bishop of Matabeleland, notes that, instead of complying in the time of adversity in which "the greatest crime was to rock the boat", ${ }^{18}$ the Catholic Church did just the opposite, offering the most sustained opposition to supremacist white regime of Ian Douglas Smith, the last Rhodesian prime minister. The Church categorically dismissed Ian Smith's declaration that "there will be no African Nationalist Government in my life time"19 as prohibitive to racial harmony, because "racial discrimination cannot be the true foundation of peace" ${ }^{20}$ Peace is seen as the basic building block of human flourishing. Robert Gabriel Mugabe, the first prime minister of independent Zimbabwe and long-time president, was all praises for the role played by the Catholic Church during the war. He told a British television channel in 1980 that,

The Catholic Church played a very significant role in the liberation struggle. Not that they fought with arms as we did; but they opposed racism and refused to be made an agent of the government in implementing racial policies. We valued the support which the Church gave us as it helped internationalize our grievance and helped to mobilize international support for us. Within the country it gave us a broader base than the one which we ourselves, acting entirely on our own, could have created..$^{21}$

Praxis and Transformation in Africa? Mankon: Langaa Research and Publishing, 137-158.

Banana CS. 1996. Politics of Repression and Resistance: Face to Face with Combat Theology. Gweru: Mambo Press, 27.

17 McLaughlin J. 1996. On the Frontline: Catholic Missions in Zimbabwe's Liberation War. Harare: Baobab Books, 4.

18 Skelton K. 1985. Bishop in Smith's Rhodesia. Gweru: Mambo Press, 26, 106.

19 Skelton K. 1985. Bishop in Smith's Rhodesia, 5.

20 RCBC. 1976. The Road to Peace: Pastoral Guidelines. Gweru: Mambo Press, 7.

21 United Kingdom, ITV, 30 November 1980; see Randolph RH. 1985. Dawn in Zimbabwe: The Catholic Church in a New Order (A Report on the activities of the Catholic Church in Zimbabwe for Five Years (1977-1981)). Gweru: Mambo Press, 42. 
To achieve that the Catholic Church put in place several means to try and ameliorate the volatile situation, skewed towards the emasculation of blacks at the hands of their European colonisers. The package used by the ZCBC to voice the Church's concern is considered below as follows: use of pastoral letters and commissions, publications of community newspapers, working with other churches and mediation. The five-fold package has left an enduring legacy of the Church in its endeavour to scaffold human flourishing.

\section{PASTORAL LETTERS AS INDELIBLE PROPHETIC VOICE}

Pastoral letters are the most abundant form of historical preservation chronicling the Church's robust involvement in the history of Zimbabwe. They are historical documents available in every parish and available to the hands of interested readers. Though they are dogmatically undergirded by the STC, they are written out of wide consultations of both the clergy and the laity, making them much more than just theological formulations by bishops. In fact, they are accurate excerpts of church history in Zimbabwe. ${ }^{22}$ On publication days, they are often read in every parish and in the language accessible to the majority of the parishioners: English, Shona or Ndebele. They conceptualise the problem in terms of the STC and then proffer the best possible solution. The solution, though embracing the aspirations of both the political elite and the masses, is generally taken as a prophetic promulgation meant to scaffold the suppressed development of the majority.

\section{GENESIS OF COMBATIVE PROPHETIC THEOLOGY: RCBC PASTORAL LETTERS}

The genesis of combative prophetic theology is associated with the pastoral letter published by Bishop Lamont for the Diocese of Umtali in 1959. It chided the colonial government for disrespecting human dignity by alienating means of production from indigenes, before putting them under exploitative cheap labour, which circumscribed indigenous progress. Some indigenes worked as contract labourers, or tenants on their former land, paying rents to settler or absentee landlords. ${ }^{23}$ Since the new landlords owned both the land and its occupants, the letter was therefore appropriately named, The Purchased People, ${ }^{24}$ which satirically addressed their dehumanisation on the land of their forefathers. The letter called upon the authorities claiming to be fighting for Christian civilisation to remember that blacks as imago Dei deserved equal respect and security as a basis for their progress. The international community accepted the letter as succinctly summarising the problem on the

22 Gundani P. 2008. "Prophecy, Politics and Power: Changing Relations Between the Catholic Church and the Zimbabwean State (1980-2007)". Paper presented at St. Augustine College, South Africa, 13 March, 3.

23 Moore DS. 2005. Suffering for Territory: Race, Place, and Power in Zimbabwe. Harare: Weaver Press, 131.

24 Bishop Lamont. 1959. The Purchased People. Gweru: Mambo Press. 
ground. For that reason, the letter was translated into fifteen languages, making it available to a wider audience. ${ }^{25}$ This internationalised the Rhodesia problem in an attempt to bring pressure on the state to rescind its erroneous decisions, but the state pressed ahead with its programme of under-developing blacks.

Peace Through Justice ${ }^{26}$ was the first RCBC joint pastoral statement on national issues. It compared the racially conceived 1961 Constitution to Nazism, which championed the superiority of the Aryan race. This eulogising of one race at the expense of the rest was a dangerous trepidation of justice precedential to the Jewish Holocaust and insecurity throughout Europe. The Second World War was the logical outpouring of revulsion against selective justice, aimed at the reclamation of the lost freedoms. The prophetic voice of the Church warned against the possible repeat of history in the form of black unrest in Rhodesia. Though the use of such blunt terms as "Nazism" did not go down well with the authorities, the Church remained resolute that it was right to forestall potential setbacks while they were still possibilities, with minimal casualties. The state paid a blind eye to Church warnings and went on to meticulously implement its programme of racial meritocracy intended to make Rhodesia "a bastion of white supremacy". ${ }^{27}$ The state went ahead with the planned December 1962 plebiscite, which was boycotted by Africans in a way that further heightened racial tensions and forestalled cordial development, ${ }^{28}$ which was a sad development contrary to human flourishing.

Racial and partisan politics came to a head with the Unilateral Declaration of Independence (UDI) from Britain on 11 November 1965. Ian Douglas Smith, the last Rhodesian prime minister and his party, the Rhodesia Front (RF), broke away from the British Empire, because the Crown was more prepared to concede to the demands of the blacks than listen to those of the settlers. ${ }^{29}$ They saw the Crown position as an impediment to "separate development" coveted by white settlers. The declaration of the UDI coincided with the closure of the Second Vatican Council, which had conceded much to Latin America's position on liberation theology. The five Rhodesian bishops arrived from Rome fired by the combative liberation theology, which was then prevalent, to find the masses further squeezed by the new laws which contravened the principle of freedom of participation. The locals had been taken out of the political arena by Ian Smith, who dreamt of no nationalist government in a thousand years. ${ }^{30}$ His coat would rather succeed him than giving space to blacks. That kind of rhetoric bred mistrust and hatred between races in flagrant opposition to the STC.

25 McLaughlin, On the Frontline: Catholic Missions in Zimbabwe's Liberation War, 13.

26 RCBC. 1961. Peace Through Justice. Gweru: Mambo Press.

27 Gundani P. 2005. “The Processes Surrounding the Birth of the Justice and Peace Commission in Rhodesia (Zimbabwe)", Studia Historiae Ecclesiasticae 31(2):174.

28 Mungazi D. 1991. The Honoured Crusade. Gweru: Mambo Press, 89.

29 Skelton K. 1985. Bishop in Smith's Rhodesia. Gweru: Mambo Press, 5.

30 Mungazi, The Honoured Crusade, 90. 
The RCBC responded on 28 November 1965 with A Plea for Peace, a tersely worded document which bluntly attacked the "atheist state". It called for solidarity in place of racial and partisan politics. ${ }^{31}$ The pastoral letter called for urgency in redressing the situation, including reverting back to the Crown by abolishing the illegal arrangement caused by the UDI. The bishops reiterated earlier messages that the state should tend more towards common good and subsdiarity, rather than pitying one race against the other. ${ }^{32}$ The RCBC categorically rejected the state claims that it was struggling to contain the threat of communism, saying instead that the state was actually creating conditions that would nature communism, which needed urgent reversal. ${ }^{33}$

In the Land Tenure Act and the Church, ${ }^{34}$ the RCBC hammered so much on the principle of association which had been done serious blows by the Constitution Act No. 54 and the Land Tenure Act No. 55 of 1969. The two acts proposed separate racial developments, including areas of domicile and property ownership. The Church was shocked by the clauses that promulgated separate racial worship, and domicile for the clergy and the religious. Catholic priests, nuns and brothers of varied races could no longer live or have fellowship together. This was too much for the RCBC which proposed disobedience to such laws, which contravened the long-established principle of freedom of association. ${ }^{35}$ By complying with the new state laws the Church would be contravening its own principles. The RCBC, therefore, threatened to close all its institutions (schools, hospitals, etc), which were amongst the best coveted by the political elite. This forced the state to overlook some cumbersome requirements on registration and ministering to the Church. ${ }^{36}$ This improved racial integration and racial progress within the Church.

The Church was clearly in solidarity with the indigenes disadvantaged by the continuous land alienation. This brought serious friction between the Church and the state, leading to missionary deportations starting March 1970, as Church institutions took the lead in opposing the new undemocratic laws. ${ }^{37}$ The state meticulously implemented the draconian Law and Order Maintenance Act of 1959, which seriously curtailed freedom of association in order to thwart political movements and increase compliance with the law. Though the act reduced Rhodesia to a "police state", the Church refused "to behave as if it approved or acquiesced in

31 RCBC. 1965. A Plea for Peace: Pastoral Instruction of the Catholic Bishops of Rhodesia. Gweru: Mambo Press, 6, 10.

32 RCBC. 1963. Problems of our People: Pastoral Instruction of the Catholic Bishops of Southern Rhodesia. Gweru: Mambo Press, 5.

33 RCBC. 1976. The Road to Peace: Pastoral Guidelines. Gweru: Mambo Press, 21.

34 RCBC. 1970. Land Tenure Act and the Church. Gweru: Mambo Press, 10.

35 Randolph, Dawn in Zimbabwe: The Catholic Church in a New Order, 14.

36 Auret D. 1992. Reaching for Justice: The Catholic Commission for Justice and Peace 1972-1992. Gweru: Mambo Press.

37 The first deportee, on 9 March 1970, was Rev Fr Michael Treber SMB, the editor of the Gwelo Diocese Moto newspaper. 
racial discrimination". ${ }^{38}$ The statement of the Church on the 1969 Laws was simple: "We therefore reject them and publicly condemned them." 39 The RCBC was clear that "equality of opportunity must be guaranteed ... job reservations must be removed", 40 as precedence for non-racial human flourishing.

\section{PERSISTENT COMBATIVE PROPHETIC THEOLOGY: ZCBC PASTORAL LETTERS}

On 17 April 1980, a day before independence celebrations marking majority rule in the new Zimbabwe, the ZCBC (successor to the RCBC) issued Welcome Zimbabwe, a celebratory, but cautious, pastoral letter. The Church cautioned that "citizens ... should not, however entrust the state with disproportionate power" in their euphoria for change. ${ }^{41}$ The Church prophetic theology would not allow for too much trust because that would corrupt the new regime into assuming the same dangerous dimensions of the previous discriminatory regime, which would seriously dent new possibilities for human flourishing. In that respect, the Church maintained its prophetic role of informing the nation to be cautious of the dangers associated with certain choices that are avoidable. As anticipated by the Church, the independence government gradually became autocratic, meticulously hunting down all perceived enemies, seriously dividing the nation in the process.

The pastoral letters from 1982 to the 2017 grapple with the gradually autocratic and discriminatory government polices of Robert Gabriel Mugabe. These were evidenced by Mugabe's recanting in deeds, and eventually in words, of his 1980 statement of magnanimity that "the wrongs of the past must stand forgiven and forgotten". ${ }^{42}$ The dissimulation of reconciliation led security forces to deal with Mugabe's political competitors with impunity because of their indemnification against any suit arising from their actions, which was a serious blow to basic security needs and fair competition.

The Church fearlessly condemned indemnification of the actions of security personnel committing atrocities in the Midlands and Matabeleland North and South provinces. ${ }^{43}$ The army operations in the three provinces, codenamed Gukurahundi (sweeper of rubbish), started in 1982 and lasted until the Unity Accord of 22 December 1987. The rubbish swept away by the operation amounted to twenty

38 RCBC, Land Tenure Act and the Church, 10.

39 RCBC. 1969. A Call to Christians. Gweru: Mambo Press; Randolph, RH. 1974. Aspects of Catholic Life in Rhodesia. Gweru: Mambo Press, 199.

40 RCBC. 1974. Reconciliation in Rhodesia. Gweru: Mambo Press; Randolph RH. 1985. Dawn in Zimbabwe: The Catholic Church in a New Order. Gweru: Mambo Press, 201.

41 ZCBC. 1980. Welcome Zimbabwe. Gweru: Mambo Press, 13.

42 Raftopoulos B. 2005. "Unreconciled differences: The limits of reconciliation Politics in Zimbabwe", in Raftopoulos B and Savage T (eds). Zimbabwe: Injustice and Political Reconciliation. Harare: Weaver Press, $x$.

ZCBC. 1982. Our Way Forward: Pastoral Statement. Gweru: Mambo Press, 10. 
thousand human fatalities. ${ }^{44}$ The Church tried desperately to have the perpetrators punished, but they continued unabated with utter impunity, fully knowing that they were immune to prosecution, as long as they committed the atrocities in the name of "the party". 45 The ZCBC, however, noted that "violence, intimidation and threats are tools of failed politicians". ${ }^{46}$ The episcope asked people to take courage and vote for people who respect human rights and dignity. ${ }^{47}$ The government reacted by enacting the punitive Public Order and Security Act (POSA) (2002) and Access to Information and Protection of Privacy Act (AIPA) (2004), to effectively intimidate and "muzzle the independent media and the freedom of expression". ${ }^{48}$ These were unfortunate pieces of legislation, as human flourishing is enhanced by dissemination of accurate information and freedom of expression, but the Mugabe regime thrived on misinformation and brutal repression.

In Peace and Unity and Freedom, bishops note that they "are deeply saddened by the suffering of many people and the senseless loss of life caused by disunity, hatred and ruthless hunger for power". ${ }^{49}$ They condemned Mugabe and his party for being power hungry at the expense of the suffering masses, which retarded human progress. They also condemned media silence on "wanton killings, woundings, beatings, burnings and rapings", 50 done in the names of security and the party. Scholars were equally appalled by the acts of the Fifth Brigade which dominated the "murdering, raping, pillaging and burning". ${ }^{51}$

With the loss of the referendum to the democratic forces in 2000, Mugabe upped the "articulation of an intolerant, selective and racialised nationalist discourse". ${ }^{2}$ This was accompanied by state-sponsored evictions of white farmers from their lands in which "the agrarian bourgeoisie [ZANU PF political elite] gained immensely from land allocation". ${ }^{53}$ This worsened the situation leading to the rejection of Mugabe and ZANU PF in the 2000 and 2002 plebiscites, which became very flawed as a way

44 CCJP \& LRF. 1997. Breaking the Silence: Building the True Peace (A Report on the Disturbances in Matabeleland and the Midlands 1980-1988). Gweru: Mambo Press.

45 ZCBC. 1985. Peace and Unity and Freedom: Pastoral Statement. Harare: Social Communications, 1,6 .

46 ZCBC. 2001. Tolerance and Hope. Harare: Social Communications, 1.

47 ZCBC. 2000. Use Your Vote, it is Your Right. Harare: Social Communications, 2.

48 Gundani, "Prophecy, Politics and Power: Changing Relations between the Catholic Church and the Zimbabwean State (1980-2007)", 23.

49 ZCBC. 1985. Peace and Unity and Freedom: Pastoral Statement. Gweru: Mambo Press, 3.

50 ZCBC. 1983. Reconciliation is still Possible. Gweru: Mambo Press.

51 Martin R. 2006. "The Rule of Law in Zimbabwe", The Commonwealth Journal of International Affairs 95(384), 249.

52 Raftopoulos, "Unreconciled Differences: The Limits of Reconciliation Politics in Zimbabwe", xiii.

53 Sachikonye LM. 2005. "The Promised Land: From Expropriation to Reconciliation and Jambanja", in Raftopoulos and Savage (eds). Zimbabwe: Injustice and Political Reconciliation, 4. 
of retaining Mugabe in power. ${ }^{54}$ The ZCBC did not mince its words in describing the evils that came with stolen elections, such as increased inter-party acrimony which hurt the economy and human flourishing.

As the situation worsened, the Church published the most terse pastoral letter ever (God Hears the Cry of the Oppressed), which re-enacted the Pharaoh-Israelite nexus. ${ }^{55}$ The bishops as teachers of faith noted, "God ... is always on the side of the oppressed (Psalms 103:6)."56 Mugabe was viewed as the new Pharaoh persecuting innocent Zimbabweans, who needed a new exodus to the new Israel with just rulers. In simple terms, this meant the removal of the Mugabe regime from power and the ushering in of new leadership. Many clergymen were visited by security agents after the reading of the pastoral letter in their churches. The most vocal of the bishops, Pius Ncube, archbishop emeritus of Bulawayo, was pursued by state security personnel who classified him with the MDC "as enemies of the state", until he tendered his resignation from administrative duties. He personally lost a parent to the Gukurahundi and therefore had hands-on experience of the callousness of the state under Mugabe. For that reason, he bluntly stated, "What is wrong is wrong and what the Five Brigade did was wrong." 58

The problems of Zimbabwe did not go away with the departure of Pius Ncube, and the Church remained true to its call, reminding ZANU PF not to monopolise the Chimurenga (Liberation War) Discourse because the party was not solely responsible for bringing down the enemy. The truth was that the armed ZANLA and ZIPRA forces (now ZANU PF) and the civilian, the internal and the external, the national and the international forces, had pulled together a complexity of resources to win the war. ${ }^{59}$ Section 7.1 of the same pastoral letter urged "securocrats" to be professional and the state to be impartially. ZCBC took exception of the politicisation of the army, police, National Youth Service, food distribution and other state functions. This enduring prophetic voice of the Church was also visible in other arms of the Church like the CCJP, which endeavoured to create conducive environments for human flourishing.

54 ZCBC. 2004. A Credible Electoral Process for a Responsible and Accountable Leadership. Harare: Social Communications, 1.

55 ZCBC. 2007. God Hears the Cry of the Oppressed. Harare: Social Communications.

56 ZCBC, God Hears the Cry of the Oppressed, 6.

57 ZCBC. 2003. "Pius Ncube Refuses to Shut up", Moto. Gweru: Mambo Press, 11.

58 Samuriwo P. 2000. “Reviving a People's Lost Pride”, Catholic Church News. Harare: ZCBC Social Communications, 10.

59 ZCBC. 2011. Let us work for the common good: Let us help our country. Harare: Social Communications, 5 . 


\section{THE CCJP AS THE PROPHETIC VOICE OF THE CHURCH}

The idea of the Catholic Commission for Justice and Peace was born out of the Second Vatican Council (1962-65), which stressed that the greatest problems besetting the world were justice and peace. The council defined peace as more than just absence of war and encouraged all nations to form commissions on justice and peace. Rhodesia heeded the call by inaugurating the commission in 1972 at the height of political turmoil. Right from its conception, the CCJP aimed to forge, "ecumenical collaboration with churches and communities, with men/women of goodwill in order to seek solutions to the acute problems of world justice, development and peace". ${ }^{60}$ It was to disseminate the Social Teachings of the Church (STC) and "expected to influence men's minds" ${ }^{\prime 1}$ for the enhancement of human flourishing. Its formation was especially urgent, as racism threatened to engulf Rhodesia political landscape. ${ }^{62}$ It was part of the Church's self-renewal, which made "justice an integral and constitutive element of Christian mission". ${ }^{63}$

The commission immediately engaged in fieldwork to diagnose the escalating violence, and the Rhodesia Front was found to blame. The CCJP used the approach of engagement rather than labelling. It engaged the government on the security atrocities, but government officials rebuffed the commission leaving it with the option to publicise the shortcomings of government. That brought further tension between the Church and the state. As chairman of the CCJP, Brother Fidelis Mukonori, now a reverend Father, dealt with the atrocities of the guerrillas and reported directly to Josiah Tongogara, the ZANLA guerrilla commander, who made redresses. For that reason, the commission did not speak publicly of the guerrilla errors as they did those of the intransigent minority regime. ${ }^{64}$

Brother Mukonori was part of the contact group mandated by the RCBC to mediate between the internal and the external protagonists of the liberation war and their adversaries. ${ }^{65}$ Through the CCJP, the Church vocally opposed the 1978 internal settlement that excluded ZANU and ZAPU, liberation movements waging war from Mozambique and Zambia, respectively. The CCJP called upon the international community to reject the exclusive arrangement, which contradicted the principles of participation and common good represented by the inclusion of liberation movements. It called upon the international community to help create an inclusive regime encompassing all belligerents. Eventually that was achieved, and all parties to the conflict signed the 1979 Lancaster House Agreement, which ushered in the new Zimbabwe.

60 RCBC. 1970. News Sheet 5. Gweru: Mambo Press, 17.

61 CCJP. 2013. Catholic Commission for Justice and Peace in Zimbabwe: Bulletin 1, 1.

62 Gundani, "The Processes Surrounding the Birth of the Justice and Peace Commission in Rhodesia (Zimbabwe)", 171.

63 Gundani, "The Processes Surrounding the Birth of the Justice and Peace Commission in Rhodesia (Zimbabwe)", 172.

64 McLaughlin, On the Frontline: Catholic Missions in Zimbabwe's Liberation War, 225.

65 Randolph, Dawn in Zimbabwe: The Catholic Church in a New Order, 30. 
The Church hoped that human flourishing would improve with independence, yet political independence ushered in the silencing of churches through heightened socialist rhetoric harmful to spiritual formation. Only the Catholic Church resisted the state attempt to muzzle it, with the result that "except for the role of the ZCBC and its work in Matabeleland, and the CCJP's advocacy role following the Matabeleland massacres, the Church's attention was focused on non-political issues". ${ }^{66}$ In that case, the Catholic Church dared where others chickened out. The CCJP worked meticulously on the ground collecting evidence of the atrocities with the assistance of the Legal Resources Foundation, which assisted them in publishing a horrendous report in $1997,{ }^{67}$ hoping that the state would apologise leading to human flourishing premised on national healing.

The CCJP also assisted political prisoners in extricating themselves from arbitrary arrests through advocacy and legal assistance. They challenged the independent state's continued use of the colonial Rhodesia Emergency Powers: “Emergency Powers were used extensively by the Rhodesian regime. Regrettably, after Independence it was felt necessary to continue to make use of these extraordinary powers, some of the most drastic of which are the Emergency Powers (Maintenance of Law and Order) Regulations, 1983."68 With these powers, police officers could detain a suspect for up to 30 days without resort to court and could extend that period indefinitely using ministerial and not court powers; the CCJP maintained that this was treading on the rights of the people. Citizens were ill-treated during incarceration, and those out of custody were denied drought relief in addition to being subjected to a ban on the use of private transport to ferry foodstuffs purchases on their own. ${ }^{69}$ The CCJP stood firm in favour of freedom of choice and the right to life as guarantors of human flourishing.

The CCJP was adamant against the 1990 proposal for a one party-state, which would further entrench the authoritarian Mugabe regime which was so keen on curtailing personal freedoms. The CCJP publicly condemned the violence that accompanied the 1990 elections, which resulted in the shooting and wounding of Patrick Kombayi, a popular opposition candidate competing against vice president Simon Muzenda for the Gweru urban constituency. The CCJP was, however, impressed by the Government of National Unity (2009-2013), which was constituted following the disputed elections of 2008. The arrangement was especially good because ZANU PF and MDC antagonists were for the first time "talking to each other" ${ }^{\prime 70}$ for the common good of the nation.

66 Muchena DT. 2005. "The Church and Reconciliation: A Mission Impossible?", in Raftopoulos and Savage (eds). Zimbabwe: Injustice and Political Reconciliation, 260.

CCJP and LRF, Breaking the Silence: Building the True Peace. Mambo Press, ii. 


\section{CHURCH-RUN NEWSPAPERS AND THE PROPHETIC VOICE}

Church-run newspapers and magazines were deliberately informed by the Social Teachings of the Church (STC), which emphasised the common good. In 1946, the Salisbury Jesuit Vicariate established The Shield newspaper, which sought to reform the colonial government's electoral and labour laws through critical advocacy. Africans, though being the indigenous people, could not vote on their own land, because the law defined them as subject people rather than citizens. ${ }^{71}$ The Shield exposed the shortcomings of the electoral laws as both morally wrong and a recipe for future conflict with the potential for undoing human progress. Mounting advocacy on electoral reforms succeeded in changing the prohibitive law, but the new electoral law remained restrictive. Only propertied Africans and coloureds could vote. Though coloureds were classified by the 1969 Constitution as whites, they did not have the same rights as whites, ${ }^{72}$ and The Shield had no kind words for the anomalies. Bishop Chichester, SJ, always personally afforded Parliament a copy of the newspaper for their library whenever there were constitutional matters for their interest in the paper. ${ }^{73}$ Several issues of The Shield highlighted the plight of forced labourers transported by road and rail into Rhodesia where their rights were overlooked.

The SMB of the Diocese of Gwelo introduced Mambo Press and Moto newspaper in 1959. Unlike The Shield, which was run by the English Jesuits, who were more polite in their approach to the English political establishment in Rhodesia, the Swiss SMB were more blunt. They were ready to cooperate with various classes and churches in the dissemination of socio-economic and political justice irrespective of government reaction. Janice McLaughlin, a Catholic nun who ministered to Zimbabwean refugees in Mozambique during the liberation war, succinctly sums up the scope of Mambo Press and Moto as follows: "Mambo Press and Moto newspaper were in the forefront in voicing African opinion, and in employing and training African journalists such as Simbi Mubako, Dzingai Mutumbuka, Paul Chidyausiku, Stan Mudenge, and Justin Nyota. Reverend Canaan Banana was responsible for sales in Matabeleland."74 The paper's empathetic stance on African affairs made it the major target of the Smith government in the print media section. The first deportee was Father Michael Treber, SMB, the Moto editor. He was deported by the Smith

71 Mamdani M. 1996. Citizen and Subject: Contemporary Africa and the Legacy of Late Colonialism. Princeton: Princeton University Press.

72 Muzondidya J. 2007. "Jambanja: Ideological Ambiguities in the Politics of Land and Resource Ownership in Zimbabwe", Journal of Southern African Studies 2(33):330.

Barr FC. 1978. Archbishop Aston Chichester 1879-1962: A Memoir. Gweru: Mambo Press.

McLaughlin, On the Frontline: Catholic Missions in Zimbabwe's Liberation War, 225. These personalities became leading Africans. Simbi Mubako became minister at independence and eventual justice of superior courts; Dzingai Mutumbuka was the minister of Education who expanded the post-independence education for the black majority; Paul Chidyausiku eventually became chief justice; Stan Mudenge became ambassador and eventually foreign affairs minister; Reverend Canaan Banana became the first post-independence president of Zimbabwe. 
administration on 9 March 1970 for publishing a cartoon of a white hand crushing blacks, with the caption: "Government will be retained in responsible hand". ${ }^{75}$ The cartoon satirised idea of a "responsible hand" crashing the owners of the land out of politics. The government position was that Africans were infantile and therefore should not be entrusted with governance. The Moto editor instead presented whites as irresponsible autocrats, dashing aspirations of the Africans, which adversely affected human flourishing.

Bishop Haene, SMB, refused all subsequent calls to censor Moto, then, the major gateway for freedom of expression amidst extreme censorship by central government. He instead sanctioned Mambo Press to print ZANU party cards in the run up to its first congress of 1964, which he partly sponsored. This put Mambo Press and Moto at loggerheads with the principles of the settler government, contradicting the white supremacy theory, which all whites, including clergymen, were expected to advance. Unfortunately, by advancing white supremacy, the Church would contradict its own social teachings, undermining its own existence.

Moto retained constructive criticism of the ills of society, pointing out how the people of God should live in "brotherly love". This placed it on collision course with the corrupt post-independence government of Robert Mugabe, who ruled Zimbabwe from 1980 to 2017, before being deposed by the military. Mugabe defined patriotism as eulogising him and toeing the ZANU PF line defined by him as the only centre of power both in ZANU PF and in government. Moto would have none of it, as it voiced the STC. The Catholic News, published by the ZCBC's social communications department, continues the Catholic legacy of anthropocentric development. ${ }^{76}$ The Church continues to press for human freedoms as key drivers for human flourishing.

\section{COMBINED VOICE: WORKING WITH OTHER CHURCHES}

Bishop Haene, the first bishop of Gweru, used his influence to convene an interdenominational meeting, which produced a negative statement against the State of Emergency in 1959. ${ }^{77}$ The Church realised that unity bred more success than individualism, and therefore encouraged forming a front against negative state policies. Umbrella statements were more secure, while denominational and individual statements were more open to recrimination. ${ }^{78}$ This is true of the fates

75 Barr, Archbishop Aston Chichester 1879-1962: A Memoir, 52.

76 ZCBC. 2017. The Catholic News. Harare: Social Communications.

77 Auret, Reaching for Justice: The Catholic Commission for Justice and Peace 1972-1992.

78 Lamont, the outspoken bishop of Umtali, was sentenced to ten years in prison with hard labour in 1976, but was subsequently exiled in 1977 for producing negative statements against the government and demonstrating with the Tangwena people against their eviction from ancestral lands. Pius Ncube, the archbishop of Bulawayo, was pressured by the state to resign for complementing ZCBC statements with his own verbal pronouncements 
of Bishop Lamont, Father Treber and Archbishop Ncube, whose statements could be isolated as individual. The first two were exiled, while the latter was silenced through resignation.

In the years following 2000, bishop Patrick Mutume (RCC) partnered with bishops Trevor Manhanga (EFZ) and Sebastian Bakare (CPCA) in advancing politics of reconciliation in Manicaland. The ZCBC, the Evangelical Fellowship of Zimbabwe (EFZ) and the Zimbabwe Council of Churches (ZCC), the largest Christian groupings in Zimbabwe, mandated the three bishops to assist national dialogue. The various churches belonging to the three national communions finally came up with a document submitted to government and signed by ZCBC, EFZ and ZCC. ${ }^{79}$ The document entitled, "The Zimbabwe We Want: Towards the National Vision for Zimbabwe", defined the best way national consensus and reconciliation could be achieved. It was critical of the way ZANU PF elite and the "securocrats" advanced partisan agendas at the expense of inclusive politics. It proposed the democtratisation of all national institutions and the eradication of the politics of impunity, which was deemed hurtful to human flourishing.

When the Zimbabwe Defence Forces took over the powers of government on the night of 14 November 2017, the ZCBC joined heads of other Christian denominations in producing a press statement the following day. The statement deplored the "abrasive and exclusionary politics, characterised by increased use of ethnic identities that was now dominating the public discourse", ${ }^{80}$ which threatened national unity. The statement viewed the departure of the long-time dictator, Robert Mugabe, as "a new chapter in the history of our nation". ${ }^{81}$ It was an opportunity for the birth of the new nation, a kairos moment similar to God's creation of good out of chaos. It proposed the restoration of trust in national institutions and processes through the separations of powers of the arms of government (executive, legislature and judiciary), which would initiate acceptable inclusive development (human flourishing). This enhances the separation of party politics from government business, which eradicates the tendency to make non-ZANU PF members enemies of the state. Instead everybody should belong and receive a rightful share rather than live on handouts from those who monopolise national resources. ${ }^{82}$

against state brutality and for teaming up with Zimbabwe cricket players to demonstrate against the government during a world cricket tournament in Bulawayo.

ZCBC, ZFZ and ZCC. 2006. The Zimbabwe We Want: Towards the National Vision for Zimbabwe. Harare: Print Works.

80 ZCC, ZCBC and EFZ. 2017. Zimbabwe Between a Crisis and a Kairos (opportunity): The Pastoral Message of the Churches on the Current Situation. 15 November, 1.

81 ZCC, ZCBC and EFZ, Zimbabwe Between a Crisis and a Kairos (Opportunity), 1.

82 ZCC, ZCBC and EFZ, Zimbabwe Between a Crisis and a Kairos (Opportunity), 2. 


\section{THE CHURCH'S MEDIATORY VOICE}

During the liberation struggle, the RCBC kept an episcopal mediatory contact group comprising Schmidt, the bishop of Bulawayo, Chakaipa, the archbishop of Harare, and Fidelis Mukonori, SJ, the chairman of the CCJP. The mediatory mission was carried out to its final conclusion in 1979, when the Lancaster House Agreement was signed between the warring parties. This ushered in majority rule with a promise for greater freedoms precedential to human flourishing.

Two years into black rule, there were civil disturbances in which the ZANU PF Fifth Brigade, trained by North Koreans, spilled innocent blood in the Midlands and Matabeleland provinces, amounting to twenty thousand civilian fatalities. The Church called on both parties to initiate dialogue and took it upon itself to mediate between the two parties. Although ZANU PF tended to throw in offensive clauses, the CCJP impressed it upon Joshua Nkomo, the leader of ZAPU PF, not to reject the pact on the basis of such clauses. ${ }^{83}$ The noble Joshua Nkomo was more than prepared to sacrifice personal interests for peace and unity, leading to the signing of the Unity Accord on 22 December 1987 and bringing in the much needed peace, tranquility and development.

The military takeover of the powers of government on the night of 14 November 2017 brought Father Fidelis Mukonori back as chief mediator. He was named by Robert Mugabe as his negotiator with the military. He led the week-long negotiations that ended with the resignation of Mugabe from power and the return of the sacked vice president Emmerson Dambudzo Mnangagwa to assume the vacant presidency. Church involvement ensured a smooth handover of power, and the ushering in of what has technically been termed "the new dispensation", though led by Mugabe's protégé of the past fifty-five years.

\section{CONCLUSION}

The chapter has explored the invaluable contribution of the ZCBC's combative prophetic voice, which fought to turn every challenge faced by the nation into a kairos moment for the betterment of the people oppressed by their successive governments. Initially, the Church busied itself with inculcating the necessary skills required by industry into the indigenes, only to find them closed out by legal clauses insisting on job reservations for the white supremacists. The Church mobilised all its organs to take action against such structural injustice bent on separate developments for whites and blacks. It supported land restitution through the liberation struggle as an invaluable means of production necessary for human flourishing. When the post-independence government became more oppressive and inhibitive to human flourishing the Church not only frankly exposed such shortcomings, but also pressured the government into accepting mediation to

83 Auret, Reaching for Justice: The Catholic Commission for Justice and Peace 1972-1992. 
establish a socio-political contract capable of unlocking the macro-economic fundamentals necessary for enhancing human flourishing. It fought for the abolition all draconian laws bent on inhibiting free flow of information, freedom of choice, freedom of association and equal opportunities, all of which are deemed essential antecedents of human advancement. In short, the Church fought tirelessly to create conducive environments for human flourishing, through lobbying political leadership to devote generously to common welfare. 